The University of Southern Mississippi The Aquila Digital Community

Faculty Publications

$12-1-2005$

\title{
Playing Underground: A Critical History of the 1960's Off-Off-Broadway Movement
}

Philip C. Kolin

University of Southern Mississippi, philip.kolin@usm.edu

Follow this and additional works at: http://aquila.usm.edu/fac_pubs

Part of the English Language and Literature Commons

\section{Recommended Citation}

Kolin, P. C. (2005). Playing Underground: A Critical History of the 1960's Off-Off-Broadway Movement. Theatre Journal, 57(4), 780-781.

Available at: http://aquila.usm.edu/fac_pubs/2597

This Book Review is brought to you for free and open access by The Aquila Digital Community. It has been accepted for inclusion in Faculty Publications by an authorized administrator of The Aquila Digital Community. For more information, please contact Joshua.Cromwell@usm.edu. 
practical guide to how performances are written, staged, or filmed. Where Hatchuel is interested in the nuts and bolts of how a director transforms Shakespeare for cinema, Aebischer wants to question the tools of that transformation and the resulting mechanism itself. Shakespeare's Violated Bodies ends with a short return to her stated purpose: she means to turn "stories of loss into stories of remembrance, resistance, hope and gain" (190).

These two books function beautifully in tandem, both structurally and through their content, one book extending and answering some of the questions posed by the other. Hatchuel sets out to map cinematic constructs, their aesthetic appeal, and how Shakespeare is altered by such a medium. Aebischer, although she by no means ignores the production concerns and aesthetics of text, stage, and screen, moves into more theoretical and moral spheres; she engages with the implications of performing and reading Shakespeare through particular lenses. Hatchuel's practicality compliments Aebischer's more cerebral narrative; together, the two books offer an intriguing glimpse into the complexity of reconstructing texts as performance.

KATHRYN SLOAN University of Calgary

\section{PLAYING UNDERGROUND: A CRITICAL HISTORY OF THE 1960'S OFF-OFF- BROADWAY MOVEMENT. By Stephen J.} Bottoms. Ann Arbor: University of Michigan Press, 2004; pp. vii + 401. $\$ 35.00$, cloth.

Stephen Bottoms has written a much-needed and nearly comprehensive history of America's most important alternative theatre. Until now, New York's underground theatre has been sadly neglected, the victim of "cultural amnesia" (7), according to Penny Arcade, one of Off Off's leading performers. Coined in 1960 by Village Voice critic Michael Smith, Off Off emerged from several "cohering factors," chief of which was to provide a "low to no budget alternative" for theatre makers to the commercialism of Broadway and Off Broadway, which had "become simply a smaller-scale Broadway" (23) in the 1960s. This pioneering and provocative nonbourgeois theatre was experimental, collaborative, "radically promiscuous" (15), rooted in camp and artistic community. Situated primarily in East Greenwich Village coffee houses, Off Off for Edward Albee (whose Zoo Story offered the "sensibility" that became an Off Off "hall- mark") took over "the job of putting on the farthest, most risky plays of young writers restless" with other theatres (83). As a result of Bottoms's exhaustive search for scripts, reviews, and a series of interviews with forty playwrights, directors, and actors, he captures the Off Off movement by focusing on the complex relationships among the people, venues, and plays at four theatres-Caffe Cino, Judson Poets' Theatre, La MaMa, and Theatre Genesis-and two "itinerant companies"--the Open Theatre and the Play-House of the Ridiculous.

Bottoms privileges the "unorthodox" Off Off playing spaces. For him they define the movement and the individuals behind it. Caffe Cino, owned by quirky but indefatigable Joe Cino, who "kick started" Off Off (365), physically mirrored the gallimaufry of dramatic fare presented at the coffee houses. Cino's stage was "simply an open area of floor" where actors and patrons shared "warmth and creative community" (56). The walls revealed an even deeper truth about the unconventional and uneven dramatic fare presented there. A scrounger, Cino hunted for props on the streets of New York and plastered his walls with "scrunched up silver foil, old posters, photographs of movie stars . . . and whatever memorabilia" he could fasten up (57). Judson Memorial Church, home to the Judson Poets' Theatre, provided director Lawrence Kornfeld and composer $\mathrm{Al}$ Carmines a community space for plays that did not ask for many "material requirements," but still accommodated the dancers, musicians, actors, and scripts through which the Poets' Theatre "dismantle[d] the conventional stage/auditorium divide altogether" (79). Surrounded by the set, audiences could taste Eve's apples, hung on the walls, in a Judson production of Asphodel, in Hell Despite. Café La MaMa, developed by Ellen Stewart, characterized as a "black Marlene Dietrich" (89), initially "resembled [Caffe] Cino in many respects," but expanded into an international ensemble troupe exporting the Off Off experimental spirit. Staging a "theatre of cruelty," the Living Theatre presented Dionysus in 69 and Paradise Now, in which spectators were invited or bullied into joining the play as performers.

Although marginalized by Broadway and Off Broadway theatre and castigated by critics such as Robert Brustein, Off Off proudly claimed an astonishing number of influential playwrights whose works Bottoms skillfully contextualizes in his fascinating history. With Richard Barr and Clinton Wilder, Edward Albee opened The Playwrights' Unit in the West Village to help this "new generation of downtown playwrights." One of the most important Off Off playwrights, Sam Shepard celebrated the unique "environmental" and economic 
choices it gave his plays, such as Cowboys or The Rock Garden done by Theatre Genesis in 1965. Lanford Wilson and director Marshall Mason were both closely linked to Caffe Cino, while Megan Terry (Viet Rock) and Jean-Claude van Itallie (America Hurrah) had work done at La MaMa, as did director-designer Robert Wilson. The PlayHouse of the Ridiculous was a carnavalesque home to Ronald Tavel and Charles Ludlam. Tracing the legacy of Off Off, Bottoms convincingly demonstrates that Tony Kushner's "Theatre of the Fabulous" of the 1990s has its roots in "the distinctive blend of character-based realism and camp theatrically pioneered in the Caffe Cino plays" (365).

Bottoms deftly weaves interpretations of hundreds of plays within his cultural history of alternative theatre. He stresses that Off Off cannot be viewed as a unified, single movement but rather as a spectrum of perceptions and performances. Given the underground theatre's limited resources, its protean accomplishments were staggering. Directors, playwrights, and actors combined Greek tragedy and burlesque, Hollywood and Andy Warhol, Artaud and chaotic eroticism. Off Off experimented with everything from extemporaneous "happenings" to "antiwesterns" such as Joel Oppenheimer's Great American Desert, which combined Theatre of the Absurd techniques with Hollywood glitz, to darkly sophisticated plays on gender by Lanford Wilson and Marie Irene Fornes. Off Off also staged the American premiere of Harold Pinter's The Room and did work by Baraka. Musicals flourished in works ranging from the trivial and camp Dames at Sea, the "longest running show" at Caffe Cino, to the Broadway success Hair, which was "an unashamedly commercial popularization of off-off ideas and techniques" (9). With its outrageous (for 1968) camp humor and defiance, Hair proved to Bottoms that "the underground had gone triumphantly commercial" (291).

Although Bottoms claims his history cannot reach a conclusion, given the extensive and expansive legacy of Off Off, he does, sadly, chronicle how this vibrant underground movement either disappeared, or was transformed into a commercial venture by becoming part of a foundation or other form of outside control. But even so, Off Off played a crucial role in the cultural life of America and in the fashioning of theatre in the 1960s. In chronicling this movement, Bottoms has created a meticulously researched, sprightly written history that deserves the label definitive, or close to it. The thirty-two pages of photos from Off Off productions are strategically situated in the middle of the book, beginning with the exterior of Caffe Cino, through Charles Stanley as a drag Medea in H. M.
Koutoukas's adaptation, to KISS look-alike actors in The Moke Eater done by the Play-House of the Ridiculous. Off Off gamboled for it all.

PHILIP C. KOLIN

University of Southern Mississippi

READING THE MATERIAL THEATRE. By Ric Knowles. Theatre and Performance Theory Series. Cambridge: Cambridge University Press, 2004; pp. 229. \$70.00 cloth, $\$ 28.99$ paper.

Knowles's book illustrates an open-ended method of performance analysis that uses cultural materialism and semiotics to paint thick descriptions of context and modes of production while paying close attention to the semiotics of space and location. He asks what kind of cultural work each of his case studies accomplishes, looking closely at reviews, at the historical moment in which they were produced, and at the specific site of their production. Engaging cultural studies theorists such as Stuart Hall, performance semioticians such as Marvin Carlson, and theories of cultural materialism invoked by Jonathan Dollimore and Alan Sinfield, Knowles knits together a proposal for analysis that contributes to David Savran's call for closer attention to the sociology of theatre.

To stake his claims, Knowles offers a useful précis of reception theories and studies of the semiotics of place to build a working method that accounts for production and reception processes that create a performance with wide and various cultural meanings. Although much of his discussion of theatre practice rehearses commonplaces about the ideological implications of staff and artistic roles, theatre environment and geography, acting practices, and publicity and marketing strategies, Knowles's careful theorizing of these prosaic details underscores how foundational they are to what he calls their "culturally affirmative" (à la Marcuse) or "culturally interventionist" social work. He traces the workings of ideology in the most minute production choices and, using examples from The Wooster Group, Theatre de la Complicite, the Canadian Opera Company, da da kamera, and others, exemplifies his theory through particular moments of practice. Knowles establishes his method in a persuasive, compelling way (his argument would read very well with Herbert Blau's foundational 1983 Theatre Journal essay on ideology and theatre), then applies it to The Stratford Festival, Toronto's Tarragon Theatre, The Wooster 